\title{
New Lexical and Phraseological Faunal Units in the Language Observatory of the University of Warsaw from a Cross-Linguistic Polish-English Perspective*
}

\begin{abstract}
Szerszunowicz Joanna, New Lexical and Phraseological Faunal Units in the Language Observatory of the University of Warsaw from a Cross-Linguistic Polish-English Perspective. "Poznańskie Studia Slawistyczne" 20. Poznań 2021. Publishing House of the Poznań Society for the Advancement of the Arts and Sciences, Adam Mickiewicz University, pp. 91-106. ISSN 2084-3011.
\end{abstract}

The aim of the present paper is to discuss the new Polish faunal lexical and phraseological units from a cross-linguistic perspective. The research corpus is compiled on the basis of Obserwatorium Językowe Uniwersytetu Warszawskiego (the Language Observatory of the University of Warsaw) an online source containing the items which are in use and which have not been included in dictionaries so far. The English equivalents allocated for these units are analysed and divided into four groups: quasi-absolute, partial, parallel and zero counterparts.

KeYwords: animal terms; contrastive analysis; cross-linguistic equivalents; figurative language; phraseology

\section{Introduction}

The present paper is a descriptive study of new Polish animal words and multiword expressions. They have been chosen as the object of the study, since these items are important from a linguistic and cultural perspective (Dobrovol'skij, Piirainen, 2005). Many animal terms have

${ }^{*}$ Scientific work financed from the means of the Ministry of Science and Tertiary Education within the framework of the subsidy for maintaining research potential allocated for the Philological Department of the University of Bialystok. 
developed conventional figurative meanings included in lexicographic entries. In phraseology, faunal idioms tend to be the second most numerous, following those containing names of body parts. ${ }^{1}$ From a contrastive perspective, animal terms and phrases deserve scholarly attention because of their linguistic specificity and cultural embedment.

The names of animals have been studied from various perspectives by many linguists who discussed Polish faunal lexis and phraseology in comparison with other languages. For instance, Vidović Bolt (2005, 2007, 2011, 2020) analyses Croatian and Polish fixed expressions with animal names in the contrastive, lexicographic, and translational approach. In turn, Szerszunowicz (2011) discusses Polish, English, and Italian faunal lexis and phraseology, Szczęk (2003) and Wysoczański (Szczęk, Wysoczański, 2004) investigate Polish and German phraseological units with zoolexemes, while Rodziewicz (2007) examines comparative animal phrasemes in Polish, Russian and German. The studies tend to focus on lexicographically attested units, with less attention paid to novel faunal items and their cross-linguistic equivalents.

\subsection{Aims}

The general aim of the present paper is to discuss new Polish animal lexis and phraseological units, included in Obserwatorium Językowe Uniwersytetu Warszawskiego (lit. Language Observatory of the University of Warsaw; hereinafter OJUW) with a focus on their cross-linguistic equivalents, with the Polish-English directionality. All the Polish items share two properties: they can be classified as faunal terms or expressions and they are neologisms with no standard systematic lexicographically attested English equivalent.

The Polish language is compared with English for the following reason: English functions as a modern lingua franca, so it is generally assumed that English influences Polish, which is attested by numerous borrowings

${ }^{1}$ Phraseology is understood in the broad sense, i.e. the fixedness is the common denominator for all kinds of reproducible language units: collocations, idioms proper, pragmatic phrasemes, proverbs, sayings, etc. (cf. Chlebda, 2003). 
of English origin. ${ }^{2}$ The comparison of these two languages allows for determining to which extent this tendency is observed in the new animal units used in modern Polish.

The study of Polish faunal items excerpted from OJUW involves allocating their English counterparts, which has not been done in a systematic way so far, with the view to classifying them into several groups of crosslinguistic equivalents, according to the degree of interlingual correspondence.

\subsection{Research corpus}

Many factors, including the acceleration of technological development, contribute to an increasing influx of new language items. The process of compiling and editing traditional dictionaries is complex and time-consuming. Thus, online resources of lexicographic character, being able to process new units within a short period, offer new possibilities for lexicographers. One of such online projects is OJUW. Its aim is to register and describe new lexical items such as borrowings, derivative neologisms, semantic neologisms and phraseological neologisms, in an online dictionary. In order to be included, a unit should meet the following criteria: appear in the Polish language after 2000; not be registered in any of the greatest dictionaries of Polish or foreign words; to be in use or to be gaining popularity in the standard variety. The items, now more than 1000, are provided by Internet users or taken from the editorial board's collection started in 2004.

OJUW contains various animal terms and multiword expressions with faunal constituents. ${ }^{3}$ All animal items, both figurative and non-figurative,

${ }^{2}$ The influence of English is observed in many languages (Furiassi, Pulcini, Rodriguez Gonzales, 2012). In this context, it is worth mentioning the Global Anglicism Database project (GLAD). English borrowings in Polish have been studied extensively by Witalisz (2007, 2015, 2016) and Mańczak-Wohlfeld (1994, 2006) who, apart from contributing papers on different aspects on English loans, edited a dictionary of English borrowings in Polish (SZA, 2010). It should be emphasized that in the recent decades, borrowings from English have been discussed by many Polish scholars, e.g. Markowski, Sękowska, Zabawa, Mycawka, Moch, Urban.

${ }^{3}$ All definitions of animal units are given after OJUW. In some cases, they have been abridged. 
were included in the research corpus of 68 Polish units which contains: animal names, their derivatives or phrases with such terms, for instance: żótwik (a diminutive form of żólw 'tortoise') 'a gesture, usually a welcome greeting, in which one person touches the other's fist with their own,' szczęśliwa kura (lit. 'a happy hen') 'a free range hen' (47 units); lexemes related to animals, for example: paszomat 'feed dispenser' - pasza 'feed' (7); words that may be associated with animal names, e.g. matz - an informal term meaning 'husband' derived from the formal word matżonek 'husband' by clipping is associated with the homonymic lexeme matz 'sea or freshwater mollusk' (11); lexical items with prefixes related to the world of fauna, for instance: ichti(o)- (e.g. ichti(o)wegetarianizm 'a way of nourishing excluding meat, but allowing fish') and kyno- (e.g. kynoterapia 'therapy based on activities and playing with a dog, dog therapy') (3).

\subsection{Methodological framework}

The notion of equivalence is of paramount importance for modern studies, either literature- or language-oriented. ${ }^{4}$ The theoretical approach to cross-linguistic equivalence is developed mostly by translation scholars (Nida, Taber, 1982; Nida, 1995; Baker, 1992; Koller, 1995), nowadays research is also conducted in the framework of cognitive linguistics (Tabakowska, 1993, 1995), which offers promising prospects of further elaboration in this field. It should be underscored that cross-linguistic equivalence can be viewed as correspondence at the level of translation and at the level of the system (systematic equivalence) (cf. Coseriu, 1997; MEP, 69; Toury, 1995; Dobrovol'skij, 2011).

Being of systematic character, the present study is conducted within the framework of contrastive analyses (cf. Colson, 2008). The traditional set of parameters used in a contrastive analysis is enriched with an additional criterion, i.e. the presence or absence of animal reference. As neologisms not included in lexicographic works, the units do not have recognised cross-linguistic equivalents, which involves choosing a word or

${ }^{4} \mathrm{An}$ outline of various concepts of equivalence is presented in Mała encyklopedia przekładoznawstwa (MEP, 68-75). 
phrase meeting the criteria of an interlingual counterpart. The prospective equivalents have been searched for in traditional dictionaries of the English language (WSPA), online dictionaries (BAB; UD) and various websites, for instance those selling products named by the analysed units.

A contrastive analysis determines the relation of the source language unit and its target language counterpart in terms of their systematic correspondence. For establishing the counterparts, the semantic criterion is the major factor. Another parameter of comparison is grammatical properties of the compared units. It is followed by the stylistic value carried by the prospective interlingual equivalents. ${ }^{5}$ The imagery and pragmatic characteristics are also important in terms of cross-linguistic correspondence (Szerszunowicz, 2008). The study allows for distinguishing several kinds of equivalents which are discussed and exemplified in respective subchapters.

The term quasi-absolute equivalent is preferred over the beforehand used absolute or full equivalents, since it is improbable that the units compare have identical features (Fiedler, 2007; Szerszunowicz, 2009). It can be assumed that they are bound to differ in some parameters, for example, frequency. Therefore, to sum up, it can be said although undeniably the degree of their equivalence is the highest in the typology proposed, the differences will still occur providing that many parameters are scrutinised. It is assumed that due to the influence of English, this group will contain lexical and phraseological borrowings, both loans proper and calques (EJO, 284).

Broadly speaking, partial equivalents are pairs of source language units and target language units which exhibit a high degree of cross-linguistic correspondence with subtle differences allowed. Such discrepancies mainly occur in the composition of lexical constituents and/or structure. It should be stressed that the imagery of the units compared is identical or very similar, i.e. no major changes in the figurative aspect are allowed (cf. Szerszunowicz, 2010).

${ }^{5}$ From a cross-linguistic perspective, another parameter of paramount importance is the frequency of the two units compared. The values obtained for a source language item and its prospective equivalents may differ greatly, thus affecting the relations of correspondence. In the present study, the analysis of the parameter has not been conducted because of the recent character of the Polish animal terms and phrasemes. Due to such chronological markedness, the occurrence of Polish faunal terms and expressions can be expected to be much lower than that of their English equivalents which have been used for longer time. 
The research corpus also includes examples of parallel equivalents, i.e. source language units with semantically identical target language equivalents which differ in other parameters, major and minor alike, including the combination of lexical constituents and structure. Such equivalents are distinguished in particular for figurative words and polylexical expressions since the differences in lexical composition results in the change of imagery. The last group is composed of the zero equivalents, i.e. source language units which do not have corresponding items in the target language (Szerszunowicz, 2016). They result from the existence of a linguistic or cultural lacuna in the compared systems. Their counterparts are either lexical items or loose combinations of words.

\section{A contrastive analysis of Polish animal units in OJUW and their English equivalents}

The analysis conducted for the purpose of the present study allows for classifying the units into four groups. The classification is of scalar character: quasi-absolute equivalents are the most similar units; they are followed by partial counterparts which also exhibit a high degree of congruency. The next group, parallel items, is composed of the source language units and their target language equivalents expressing the same meanings but differing formally and/or in terms of other properties, for instance, stylistic value. The units whose equivalents are hard to find fall into the last category, i.e. lacunary items.

\subsection{Quasi-absolute equivalents}

The first group of cross-linguistic equivalents comprises 37 Polish words and phrases which have close equivalents in the English language, i.e. units that have identical semantics, highly similar grammatical properties and contain an identical faunal component. 


\subsubsection{English borrowings}

In the analysed research material, many units belonging to this category are direct borrowings from English, for example: Pol. cocooning 'lifestyle consisting in spending most time at home' - Eng. cocooning, Pol. bitchface / bitch face / biczfejs 'unpleasant facial expression, especially in a woman' - Eng. bitchface, Pol. copycat 'an imitator'- Eng. copycat, Pol. cat-friendly 'friendly for cats' - Eng. cat-friendly.

In several cases, the borrowings are adapted into the Polish word formation system, as it is the case with the hybrid unit camelowy (adj. 'camel') and its English equivalent camel. Furthermore, the addition of the Polish suffix -owy may result in a more precise meaning of the borrowing: the word petsitterka 'a female petsitter' indicates that the person described is a female, whereas the English word petsitter is a dual gender item.

Apart from direct borrowings, the corpus includes English calques, both lexical, like Pol. monopłetwa 'monofin' - Eng. monofin, and phraseological, as attested by Pol. dzień konia 'horse's day' - Eng. horse 's day, Pol. wyścig stoni 'elephant race' - Eng. elephant race, Pol. wyprowadzacz psów 'dog walker' - Eng. dog walker. Another example includes the information technology Polish term styl wielbładzi (lit. camel style) 'camel case,' whose English equivalents are manifold: Camel Case, camel Case, and camel caps, and a more formal compound medial capitals which can be classified as a parallel equivalent.

Very few English borrowings have Polish neologistic synonyms. Such relation is observed in the case of the following pairs: Pol. birdwatcher 'an amateur of birdwatching' - Pol. ptasiarz ('birdwatcher;' a word derived from the Polish term ptak 'bird') - Eng. birdwatcher, Pol. birdwatching 'watching birds in their natural environment as a hobby; ornithological tourism' - Pol. ptasiarstwo 'birdwatching'- Eng. birdwatching.

To sum up, it can be observed that generally speaking, the above discussed items differ in their markedness: Polish units are tinted with foreignness and novelty, while their English counterparts tend to lack these two qualities. Nevertheless, they can be treated as pairs of units exhibiting a very high degree of cross-linguistic equivalents. 


\subsubsection{Other quasi-absolute equivalents}

Among the analysed units, there are also items expressing the same meaning which to a great extent resemble lexically and structurally their English equivalents. It allows for classifying them as quasi-absolute equivalents. In the research corpus, these units tend to employ elements of Greek or Latin origin, for instance, an international suffix (e.g. derivatives with -ism, -holic) rather than be English loans. Yet, it cannot be excluded that they might be secondary borrowings incorporated into Polish via English.

This cross-linguistic relation can be observed in the case of the terms alpakoterapia 'alpaka therapy' and alpakoterapeuta 'alpaka therapist' and their English equivalents, respectively alpaka therapy and alpaka therapist. The words terapia and therapy can be traced back to the Latin terapia and the Greek $\theta \varepsilon \rho \alpha \pi \varepsilon i \alpha$ 'service, medical treatment. ${ }^{9}$ Another example is the pair composed of the Polish formation pingwinarium 'pingwinarium' and its English equivalent pinguinarium: both are created by means of the suffix -arium forming nouns denoting a place.

A foreign suffix can be added to either Polish or English stems, which is exemplified by the pairs of the following words: Pol. kot 'cat' - kotoholizm 'cataholism,' Eng. cat - cataholism. It is worth drawing attention to the fact that the Polish terms kotoholik 'a male who loves cats' and kotoholiczka 'female who loves cats' have only one English equivalent which is cataholic 'person who loves cats.' The Polish lexical items carry the information concerning the sex of the cat lover, so they are semantically more specific. From a cross-linguistic perspective, they still bear a high degree of correspondence.

\subsection{Partial equivalents}

In the research corpus, there are 9 pairs meeting the criteria of partial equivalents. It should be emphasized that in several cases given pairs of equivalents may be either treated as quasi-equivalents or partial

${ }^{6}$ The word therapy can be qualified as an internationalism, since it appears in a similar form in various languages, for instance: Fr. thérapie, Germ. die Therapie, It. la terapia, Port. la terapia, Sp. la terapia, Swed. terapi. An analogous list can be compiled for the noun therapist. 
equivalents, depending on the criteria adopted. Therefore, quantitatively, these two groups should be counted together as close equivalents.

\subsubsection{Units with identical animal constituents}

The first subgroup of partial counterparts is composed of Polish and English units which contain an identical faunal constituent. Yet, when compared, these equivalents show differences in certain properties, for instance, in the structure. This relation can be illustrated with the example of kaczkomat 'a duck food dispenser' whose English equivalent is a multiword construction duckfood dispenser. In turn, the Polish verb kangurować (lit. to kangaroo), meaning 'to hold a newborn baby on one's stomach or on one's chest so that its skin would directly adhere to the skin of the person keeping it,' has a compound equivalent of to kangaroo (mother) care. ${ }^{7}$

Special attention should be paid to the lexical items which have numerous equivalents with different wording. For instance, as already mentioned, in Polish the word antyptak (lit. antibird) meaning 'spikes mounted on window sills, cornices etc. preventing birds from staying in places protected in such a way; a silhouette of a bird of prey placed on windows and screens to scare away other birds' has several English counterparts with various animal references, both identical to the Polish ones, like bird spikes, bird deterrent spikes, bird control spikes, and different ones: anti-roosting spikes, pigeon spikes, roost modification. A similar relation of cross-linguistic asymmetry is observed for the Polish noun antyszczekacz 'an electronic device which enables teaching the dog not to bark persistently' whose all English systematic equivalents contain the component bark: bark deterrent, anti-dog barking device, bark control device, anti-bark deterrent.

Irrespective of identical faunal components, the pairs of equivalent units may exhibit differences conditioned by various factors. The noun pieset (pies 'dog' + the suffix -et) and its English equivalent constitute an illustrative example. The Polish word can be described as a creatively coined counterpart of the English noun dohg used in a series of Internet memes with a shiba-inu. In Polish, the lexeme in question, which pertains to youth jargon, has two meanings: the first one is the name of the Internet meme hero, the other is

\footnotetext{
${ }^{7}$ In English, the expression kangaroo mother care is abbreviated to KMC.
} 
a humorous term for a dog. In Polish, the noun kotet has also been coined as an informal name for a cat (cf. 2.4.). As a result of such word formation, these two lexemes constitute a pair of jocular pet terms which are conspicuous because of the suffix -et added to the animal name.

\subsubsection{Units with different animal constituents}

The second subgroup of partial equivalents contains examples in which the animal term is not the same in both languages. From the perspective of imagery, it is of great importance to which degree the two faunal names differ. Providing that they both come from the same class or name similar animals, the two pictures evoked by the units are fairly alike. Yet, if the two zoolexemes differ greatly, it will result in lowering the degree of equivalence - such items will be classified as parallel counterparts.

In the corpus of animal lexis and phraseology in OJUW, an example of the former relation occurs: the Polish informal word glonojad 'algae eater' is used as a depreciative term referring to females who have had their lips excessively enlarged. Its English equivalent is the expression fish lips: the animal constituent fish is a hyperonym of the noun glonojad. Another equivalent is trout pout, a phrase which contains a name of a species. It is worth adding that it employs rhyme and rhythm. In Australian English, the unit slug lips is used. Undeniably, the image of an algae eater is particularly vivid, yet it should be admitted that even though the references are not identical, the Polish and English units in question still evoke similar connotations.

An interesting example of a complex relation occurs between the Polish term koźlak 'goatling' and its English equivalent bock. In fact, the English word is a German borrowing meaning 'he-goat' which functions as a term for strong lager of German origin. In Polish, the name has a Polish equivalent of the same meaning which does not evoke foreignness and can be easily related to the animal of this name by language users. The English word, although close to its Polish counterpart in terms of semantics, may not automatically be associated with any animal by native English speakers. It can be assumed that it is rather viewed as a chrematonym which is used internationally. ${ }^{8}$

${ }^{8}$ Apart from the English language, the name bock is used for instance in French (la bock, la bockbier), Portuguese (bock), Spanish (el bock). 


\subsection{Parallel equivalents}

In the analysed material, there are 7 pairs which have various figurative counterparts in English, both lexical and phraseological. For instance, informal words matz 'clam' and matż (a form which can be interpreted as 'a female clam'), meaning 'husband' and 'wife,' have various equivalents, including the expressions old man and old wife. Figurative as they are, they do not carry any references to the animal stock. The imagery is completely different, moreover, Polish units might be described as more jocular and novel. Thus, there is no correspondence in these parameters in the examples.

Another pair of parallel equivalents is composed of the Polish idiom dać raka (lit. to give a crayfish/cancer) and the corresponding English unit it sucks. It should be emphasized that the Polish lexeme rak is also the term for cancer and it can be assumed that this meaning is activated in the phrase. From a comparative perspective, the two expressions in question perform the same function, since they are used as commentaries expressing a negative evaluation of the quality of the described object, situation, etc.

Furthermore, in this group, one can classify the term-like Polish items with polylexical English equivalents exhibiting lexical and structural dissimilarities and/or subtle semantic differences. To illustrate this model, the following pairs can be given: Pol. strusiarnia 'a place where ostriches are kept' - Eng. ostrich pen, Pol. hipopotarium 'a place where hippopotamuses are kept' - Eng. hippoopotamus house.

\subsection{Zero equivalents}

In the analysed corpus, there are relatively few lacunary items detectedonly 15. One of them is the idiom oktadkowa sroka (lit. cover magpie), used to refer to a person who decides to buy a book judging by its cover and evaluating it as beautiful. The expression is concise and can be viewed as a label for an attitude towards buying books. Its English equivalent is a descriptive paraphrase of the meaning.

Other examples include the verb morsować (lit. to walrus, a verb derived by suffixation from the name mors 'walrus') 'to bathe in winter in 
the sea, river or a lake' and morświnarium (lit. porpoisenarium) 'a centre of research and educative exposition of Baltic porpoises for the needs of species protection.'

This subgroup of cross-linguistic equivalents also contains the professiolectal term robopszczoła (lit. robotbee, 'a miniature drone for plant pollination' whose English equivalents are descriptive phrases like pollination drone and plant-pollinating drone. Another lacunary unit is cybermatż (lit. cyberclam), i.e. 'a mollusc used as an element of the system of monitoring water quality.' There is no English unit expressing this meaning, so that the cross-linguistic counterpart is a loose string of words, for example: a mollusc used for monitoring water quality.

As already mentioned, in Polish, per analogiam to pieset (cf. 3.2.1), the word kotet was formed (Pol. kot 'cat' + the suffix -et). It functions only as a jocular name for a cat, and it has no close equivalent in English. It tends to be used in the Internet lore, in particular in memes, often in combination with the term pieset, as illustrated below.

The word kotet can be viewed as a lacuna due to its linguistic specificity as well as strong markedness and the relation to the noun pieset, which
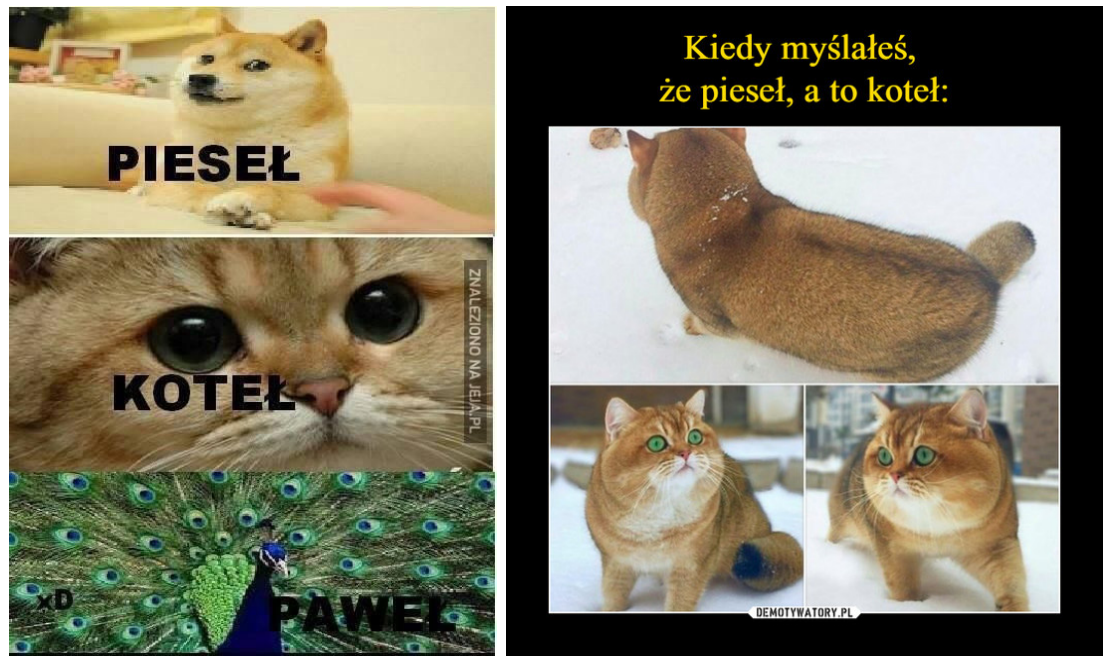

I1.1. Memes with the words pieset and kotet

Source: demotywatory.pl, 10.01.2021 
the above memes attest. It might be added that from a translational perspective, it can be re-created in English by compensation techniques in the process of translation. Yet, at the systematic level, it is difficult to provide a proper equivalent for the word kotet.

\section{Conclusions}

The analysis of broadly understood animal units in OJUW shows that this group comprises several kinds of faunal exponents: animal names and generic terms for animals, formations derived from faunal lexemes, animal-related prefixes and words, phraseological units with animal components.

The dominant group of English equivalents of the Polish animal units is composed of quasi-absolute counterparts, with as many as 37 pairs $(55 \%)$. It is followed by zero equivalents whose number amounts to $15(22 \%)$. The two other kinds are represented fairly evenly: 9 partial equivalents $(13 \%)$ and 7 parallel correspondences $(10 \%)$.

To a great extent, the fact that quasi-absolute equivalents are the most numerous is conditioned by the presence of many borrowings from English.

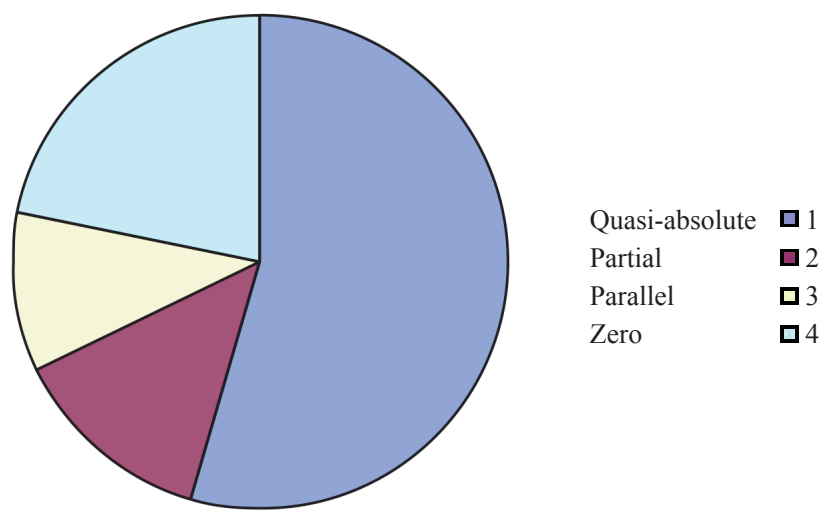

Diagram 1. The distribution of the English equivalents of Polish animal units in OJUW Source: own research. 
Almost three quarters (73\%) of all units which have quasi-equivalents are borrowings from English, either proper ones (slightly more than half of quasi-absolute equivalents; approximately one third of the total) or calques (nearly one fourth and one tenth, respectively). As a result, the degree of equivalence of all the corpus is high, with as many as $68 \%$ of close equivalents, i.e. quasi-absolute and partial counterparts, and only slightly more than one fifth of zero equivalents. In general, there are rather few cases of complex relation of cross-linguistic systematic correspondence such as that of kotet and its prospective English counterpart.

The study shows that animal terms are still productive in terms of coinage: they are used in a variety of ways to enrich the lexicon: as neosemantisms, a base for derivatives and constituents of phraseological units. The investigation aimed at comparing the recent faunal Polish items with their English counterparts to investigate the influence of the English language on this part of the Polish lexicon. It is worth analysing the equivalents of Polish new faunal units in other languages, both Slavic and non-Slavic, to examine their interlingual equivalence. It will also allow for determining the extent of English faunal borrowings cross-linguistically.

\section{References}

Baker, M. (1992). In Other Words. A Coursebook on Translation. London: Routledge. https://doi.org/10.4324/9780203133590.

Chlebda, W. (2003). Elementy frazematyki. Wprowadzenie do frazeologii nadawcy. Łask: LEKSEM.

Colson, J.-P. (2008). Cross-linguistic phraseological studies. In: Phraseology. An interdisciplinary perspective. Eds S. Granger, F. Meunier. Amsterdam-Philadelphia: John Benjamins, pp. 191-206.

Coseriu, E. (1997). Portée st limites de la traduction. "Paralléles" vol. 19, pp. 19-34. https://doi.org/10.1075/z.139.19col.

Dobrovol'skij, D. (2011). Cross-linguistic equivalence of idioms: does it really exist? In: Linguo-Cultural Competence and Phraseological Motivation. Eds A. Pamies, D. Dobrovol'skij. Baltmannsweiler: Schneider Verlag, pp. 7-24.

Dobrovol'skij, D., Piirainen, E. (2005). Figurative Language: Cross-Cultural and Cross-Linguistic Perspective. Amsterdam: Elsevier.

Fiedler, S. (2007). English Phraseology. Tübingen: Narr Verlag.

Furiassi, C., Pulcini, V., Rodriguez Gonzales, F. (eds). (2012). The Anglicization of European Lexis. Amsterdam-Philadelphia: John Benjamins. https://doi.org/10.1075/z.174. 
Koller, W. (1995). The Concept of Equivalence and the Object of Translation Studies. "Target" vol. 7/2, pp. 191-222. https://doi.org/10.1075/target.7.2.02kol.

Mańczak-Wohlfeld, E. (1994). Angielskie elementy leksykalne w języku polskim. Kraków: Universitas.

Mańczak-Wohlfeld, E. (2006). Angielsko-polskie kontakty językowe. Kraków: Wydawnictwo UJ.

Nida, E. A., Taber, C. R. (1982). The Theory and Practice of Translation with Special Reference to Bible Translating. Leiden: Brill.

Nida, E. A. (1995). Dynamic Equivalence in Translation. In: An Encyclopaedia of Translation: Chinese-English English-Chinese. Eds Ch. Sin-wai, D. E. Pollard. Hong Kong: Chinese University Press, pp. 223-230.

Rodziewicz, B. (2007). Frazemy komparatywne z komponentem zoonimicznym w języku polskim, rosyjskim i niemieckim. Szczecin: Wydawnictwo Naukowe Uniwersytetu Szczecińskiego.

Szczęk, J. (2003). Tierbezeichnungen in den Phraseologismen des Deutschenund des Polnischen. Versuch eines Vergleichs. In: Königgrätzer Linguitisk- und Literaturtage. Hrsg. J. Korčakova, J. Beyer. Hradec Kralove: Universität Hradec Králové, pp. 313-329.

Szczęk, J., Wysoczański, W. (2004). Das sprachliche Weltbild am Beispiel der deutschen und polnischen Wie-Vergleiche mit Tierbezeichnungen im Komponentenbestand. "Studia Linguistica" vol. 23, pp. 87-143.

Szerszunowicz, J. (2008). Jednowyrazowe ekwiwalenty obcojęzycznych związków frazeologicznych (na materiale wybranych języków europejskich). "Białostockie Archiwum Językowe” no. 8, pp. 175-192. https://doi.org/10.15290/baj.2008.08.13.

Szerszunowicz, J. (2009). Quasi-ekwiwalenty związków frazeologicznych w teorii, frazeografii i translatoryce. "Białostockie Archiwum Językowe” no. 9, pp. 323-346. https://doi.org/10.15290/baj.2009.09.22.

Szerszunowicz, J. (2010). Kongruencja obrazowania związków frazeologicznych a ich międzyjęzykowa ekwiwalencja. "Prace Językoznawcze” vol. 12, pp. 207-223.

Szerszunowicz J. (2011). Obraz człowieka w polskich, angielskich i włoskich leksykalnych i frazeologicznych jednostkach faunicznych. Białystok: Wydawnictwo Uniwersytetu w Białymstoku.

Szerszunowicz, J. (2016). Lakunarne jednostki wielowyrazowe w perspektywie międzyjęzykowej. Białystok: Wydawnictwo Uniwersytetu w Białymstoku.

Tabakowska, E. (1993). Cognitive Linguistics and Poetics of Translation. Tübingen: NarrVerlag.

Tabakowska, E. (1995). Gramatyka i obrazowanie. Wprowadzenie do językoznawstwa kognitywnego. Kraków: PAN.

Toury, G. (1995). Descriptive Translation Studies and Beyond. Amsterdam-Philadelphia: John Benjamins. https://doi.org/10.1075/btl.4.

Vidović Bolt, I. (2005). Prinos proučavanju biblijskih frazema u poljskom i hrvatskom jeziku (ekvivalencija zoonimskih biblijskih frazema). In: Wyraz i zdanie w językach słowiańskich. Opis, konfrontacja, przekład, vol. 5. Red. M. Sarnowski, W. Wysoczański. Wrocław: Wydawnictwo Uniwersytetu Wrocławskiego, pp. 385-394. 
Vidović Bolt, I. (2007). Frazeologia w chorwacko-polskich leksykograficznych badaniach kontrastywnych. Przykład opracowania nowego chorwacko-polskiego stownika frazeologicznego na wybranym materiale. In: Literatura, kultura i język polski w kontekstach $i$ kontaktach światowych. Red. M. Czermińska, K. Meller, P. Fliciński. Poznań: Wydawnictwo Naukowe UAM, pp. 825-836.

Vidović Bolt, I. (2011). Životinjski svijet u hrvatskoj i poljskoj frazeologiji I. Zagreb: Hrvatska Sveučilišna Naklada.

Vidović Bolt, I. (2020). Od Adriatyku do Bałtyku - świat ryb w chorwackiej i polskiej frazeologii (o zwiazkach frazeologicznych należacych do identycznych pól znaczeniowych). In: Диалогични пространства (сборник с доклади от Юбилейна славистична международна конференция. Ред. Ц. Иванова et al. Велико Търново: Faber, pp. 89-98.

Witalisz, A. (2007). Anglosemantyzmy w języku polskim - ze słownikiem. Kraków: Tertium.

Witalisz, A. (2015). Loan Translation in Polish: Word-formation, Patters, Lexicalization, Idiomaticity and Institutionalization. Frankfurt am Main: Peter Lang. https:// doi.org/10.3726/978-3-653-05793-5.

Witalisz, A. (2016). Przewodnik po anglicyzmach w języku polskim. Kraków: TMJP.

\section{Dictionaries and Encyclopaedias}

BAB - Stownik bab.la polsko-angielski. https://pl.bab.la/slownik/polski-angielski/. 7.09.2020.

EJO - Encyklopedia językoznawstwa ogólnego. (1999). Red. K. Polański. WrocławWarszawa-Kraków: Ossolineum.

MEP - Mała encyklopedia przekładoznawstwa. (2000). Red. U. Dąbska-Propkop. Częstochowa: Wydawnictwo Wyższej Szkoły Języków Obcych i Ekonomii Educator.

OJUW - Obserwatorium Językowe Uniwersytetu Warszawskiego. https://nowewyrazy. uw.edu.pl. 12.09.2020.

SZA - Stownik zapożyczeń angielskich w polszczyźnie. (2010). Red. E. Mańczak-Wohlfeld. Warszawa: Wydawnictwo Naukowe PWN.

UD - Urban Dictionary. https://www.urbandictionary.com/. 12.09.2020.

WSPA - Wielki stownik polsko-angielski PWN-OXFORD. (2004). Red. J. Linde-Usiekniewicz. Warszawa: Wydawnictwo Naukowe PWN. 